Ursula Mense-Petermann und Gert Schmidt

\title{
The social construction of enterprise strategies. Consequences of privatization*
}

\author{
Krzysztof Konecki ${ }^{* *}$
}

This article considers the impact of the ownership form on the formation of an organizational strategy by the main organizational actors. The following questions are discussed: Are there quick structural and strategic changes in the enterpise after a first structural transformation of ownership? What are socioorganizational consequences of privatization? Reconstructing the social construction of strategies in four Polish enterprises I will argue that privatization can be an intermediary condition influencing the construction of investment, sales or marketing strategies, but is not a necessary condition for the formulation of new strategies as such.

Der vorliegende Artikel erörtert den Einfluß neuer Eigentumsformen auf die Formulierung von Unternehmensstrategien durch die zentralen innerorganisatorischen Akteure. Die folgenden Fragen werden diskutiert: Ist ein schneller struktureller und strategischer Wandel nach einer ersten Umwandlung der Eigentumsform in den Unternehmen zu beobachten? Welche sozio-organisatorischen Konsequenzen hat die Privatisierung? Durch eine Rekonstruktion der sozialen Konstruktion von Strategien in vier polnischen Unternehmensoll aufgezeigt werden, daß Privatisierung zwar mittelbar die Konstruktion von Investitions-, Absatz- oder Marketingstrategien beeinflussen kann, daß sie aber keine notwendige Bedingung für die Formulierung neuer Strategien an sich ist.

Manuscript received: 18.12.96, revised: 05.03.97, accepted: 12.03.97

** Krzysztof Konecki, born 1958, Ph.D., assistant professor, Institute of Sociology, University of Lodz, major area of research interests are: organizational culture, sociology of work and organization, qualitative methodology (especially methodology of grounded theory), sociology of human resources (especially recruitment and selection process), symbolic interactionist theory of work and organization, Japanese management and culture.

Mail adress: University of Lodz, ul. Rewolucji 1905r. 41/43, 90-214 Lodz, Poland;

Email: konecki@krysia.uni.lodz.pl 


\section{Introduction ${ }^{4}$}

The social dimension in the construction of enterprise strategies concerns participation and cooperation of chief organizational actors in constructing the enterprise's strategy. Such strategy can be developed methodically according to the pattern of organizing the subsequent so-called strategic sessions (Obloj 1994), during which the entire management team assisted by a trainer builds fully deliberately and apriori (before action) a new strategy of the firm's growth (Kotler 1994:57; Stoner/Wankel 1992:95).

However, enterprise strategies are developed also processually over a longer period of time in a less orderly manner frequently not fully realized by their main authors and executors. They are not aware of the process, because strategies emerge through long negotiations, games and other interactive processes or organizational accords (consensus) reached by the chief organizational actors.

It appears that organizational actors do not frequently have a clearly defined goal and even more seldom they have coherent plans. Nonetheless, their activities are not determined, although they are subject to certain constraints and make sense even when such sense is difficult to perceive from the viewpoint of organizational goals (Crozier/Friedberg 1982; Strauss 1993).

The sociological analysis of a strategy encompassing interrelationships between actors in the process of formulating strategic goals and fields of their activity (Crozier/Friedberg 1982) allows to reconstruct the rationality of actors within the socio-organizational context and explain the strategy's construct through their experiences. The strategy is, thus, understood as a principle inferred ex post from regularities present in empirically observable behaviours (ibid:59).

The organization ceases to operate as an isolated abstraction determined by 'hard' variables such as 'ownership' (private or state), 'financial resources' or 'competitive market', and it is filled in by a network of mutual relations and dependencies of organizational actors, who through constructing strategies in daily interactions and activity create and change the organization in long term process. Strategy has processual character than apriori built structure. It is rather 'a processual ordering' of organizational reality (Strauss 1993:245-262). Such

4 The research was conducted jointly with Prof. J. Kulpinska within the framework of research project KBN No. 9.00205: "Social and cultural determinants of rationality of management activities in industrial companies in conditions of ownership transformations". (1994-1996). A version of the paper was presented on a workshop: 'Eastern Europe in Transition - First Empirical Results of Industrial and Organizational Sociology’, Nuremberg, 14-16.07.1996. 
perception of the organization has, thus, a sociological character. 
New organizational strategies are formulated once the turning point ${ }^{5}$ appears in the organization or it occurs along with the emergence of a definite and new organizational culture ('definition of organizational reality') with a significant and indispensable participation of the organization's leader or a group supporting him (Konecki/Kulpinska 1995).

Our studies of the formation of new organizational strategies in the Polish socio-economic reality in the 1990s were carried out in four industrial companies (and partly in the fifth company) in the city of Lodz. ${ }^{6}$ The

5 The turning point in an enterprise history is associated with a point of time since that have started changes in methods of management and relations with the environment. The changes has either objective dimension (changes in managing procedures and in organizational structures) as well as subjective one i.e., the perception of the changes by managers and employees and the location of the starting point of transformation in time.

6 The studies in question had a character of field studies using the methodology of grounded theory (Strauss 1987; Konecki 1989). The hypotheses and conclusions to be found in the paper are based primarily on the data gathered in the course of free interviews recorded on cassettes, which were conducted with the top management of the companies (40 free interviews) and a questionnaire survey conducted with foremen (94 questionnaires). The first company was a state-owned enterprise (textile) called Toffi (names of enterprises are changed) producing woven and knitted fabrics for clothing companies in Poland and abroad. The enterprise was set up in 1969. In the 1970s and the 1980s it produced primarily polyester fabrics and knitted fabrics - the so-called cremplene (made from polyester fibre). The enterprise's production was mainly export-oriented, with most of its exports going to the former USSR. In the 1970s the enterprise had 7,000 employees and it was one of the biggest industrial companies in Lodz. At the present time, the enterprise employs 700 persons and produces cotton fabrics. The enterprise records profits and its management evaluate its economic situation as good. Wages range around the mean national wage.

The second enterprise is the employee-owned partnership Elena S.A. privatized in 1992. It manufactures cosmetics: shampoos, nail varnish, deodorants). The employees are its sole shareholders. About $80 \%$ of employees hold shares, with the majority shareholding belonging to the partnership's management. The enterprise has a 70-year history. It employs 430 persons (the number of employees did not change after privatization). In the 1970s and the 1980s it exported most of its products to the former USSR (35\% of output in 1989). The export to the USSR stopped in 1990. At present the enterprise records profits and wages are a little higher than the national average. 
researchers seek to verify the hypothesis about a significant (or insignificant) impact of the ownership form on the formation of an organizational strategy by the main organizational actors, i.e. managers, trade union activists, functional units and employee councils in state-owned enterprises, and to determine how this strategy is perceived by the intermediate management level, which is by foremen.

Moreover, we formulated following research questions:

- Are there quick structural and strategic changes in the enterprise after a first structural transformation of ownership?

- What are socio - organizational consequences of privatization?

The privatization is one of the methods of transforming of Polish enterprises. The state enterprises are being privatized but public sector is still important in Poland. There 3,5 thousands of state enterprises, 386 state treasure owned stock companies, 11 banks and 3 insurance companies still wait for privatization. More than $76 \%$ of value of enterpises designed for privatization concentrate in 176 large state enterprises (in 1996).

The third enterprise under survey was Nika Ltd. electro-engineering company, which changed its ownership form in 1992. It was established as a result of splitting the former company into two parts. One of them was to be liquidated and the other, more healthy part was transformed into a limited liability company. The majority interest in the company is held by the Agency for Development of Industry (ADI is a joint stock company set up by the Government, whose task is to assist and transform state-owned enterprises). The ADI took part in transforming the enterprise under a strong political pressure of the Solidarity trade union, which had been organizing strikes in the enterprise earlier and had even arranged a visit of the Prime Minister in the enterprise. Another major shareholder is a thermal power station being one of the enterprise's creditors. The employees hold only 10 shares, which is a fraction of one percentage point of all shares. The enterprise does not record profits. It employs 450 persons. The average wage in the enterprise reaches twothirds of the mean national wage.

The fourth enterprise under study was the clothing company Proc. It was one of the largest clothing companies in Poland in the 1970s and the 1980s. Its main product were men's overcoats exported abroad or sold in Poland. In the 1980s successful attempts were made to reduce the exports to the Soviet market. In October 1991 the enterprise was privatized and its shares were listed on the stock exchange and sold on the free market. Its main strategic investor was an insurance company W., which holds the majority interest, that is $25 \%$ of shares. Following the bankruptcy of W., the majority interest is held by the trustee of W., which complicates considerably the ownership status of Proc. The enterprise manufactures ca. 200,000 overcoats a year. Its products are mostly exported, with subcontracting services (CMT) accounting for $60 \%$ of the whole production, $30 \%$ is sold on the domestic market and 10\% exported. The amount of sold production in 1996 is smaller than in the previous year and profits lessened considerably. It employs 2,100 persons, and the number of employees has not changed since the time of its privatization till 1996. 
The private sector in Poland contributes to 58\% of GNP, comparing to $70 \%$ in Hungary, 67,2 in Chech Republic and 63 in Slovakia. ${ }^{7}$

\section{Organizational strategies - attempt at reconstruction}

\section{T O F F I - state-owned enterprise}

Toffi has an offensive definition of the supporting of organizational reality. ${ }^{8}$ It is characterized by a positive and activistic attitude to the company's environment, a sales orientation, and an assumption about the indivisible power held by the organizational leader and great importance of human relations and human resources. The turning point occurred here relatively early, that is in 1981. Hence the present orientation at sustaining the exisiting definition of organizational reality, which proved its validity also in economic terms during difficult periods over a longer time (Konecki/Kulpinska 1995).

Within the strategy reconstructed by us and implemented at Toffi, there can be distinguished a dominant substrategy, which distinguishes itself from among other strategies being a substrategy of shaping human resources. The actions of rational shaping of human resources coincided at Toffi with the turning point and the appointment of a new managing director supported by a group connected with him (in 1981). It was in that year that an 'extensive and an intensive shaping of human resources' began. It is the managing director and not the personnel department who promotes such strategy.

'The extensive shaping of human resources' involves a gradual reduction of employment (over a 12-year period from 2,100 employees to 650 in 1996), elimination of inflexible and incompetent employees, and improvement of labour discipline. The reduction of employment and the improvement of discipline are perceived by almost all foremen at Toffi (questionnaire findings).

7 The growth of GNP in Poland was 6.9\% in 1995, in Slovakia 6.5\%, in Chech Republic $5.2 \%$. The rate of inflation in Poland was 22\% in 1995, in Chech Republic 9.1\%, in Slovakia 7.2\% and 28.2\% in Hungary (Golata/Szoszkiewicz 1996:45-46).

8 A colloquial definition of the organizational reality would include the values, taken - for granted assumptions and convictions of the main organizational actors followed by strategies of activity connected with them. These are organizational leaders who delimit the frames and ways of defining the organizational reality in the place of work, and such definition is a point of reference for activities of all organizational actors (Smircich /Morgan 1982; Berger/Luckmann 1993; Schein 1988). Of course, the definition is subject to some modifications and changes, with the most important of them taking place in times of breakthrough or turning points in the operation of formal organizations (here: industrial companies). It is at such times that new organizational leaders can appear, who will define anew the values and assumptions of strategies concerning organizational activities (Konecki/Kulpinska 1995). 
The employees leaving the enterprise were not replaced by new ones. Instead organizational and wage changes were made so that the tasks of employees leaving the enterprise could be taken over by others. The number of employees was also reduced by separating the manufacturing plants, which used to belong to Toffi's headquarters in Lodz.

'The intensive shaping of human resources' consists in launching intensive training courses at Toffi, job rotation, creating an internal labour market (promoting own employees to management positions), closely scrutinizing newly recruited employees, introducing flexible production and working time, and individual wage rates. Most foremen confirmed in the questionnaires the presence of an intensive dimension of the above substrategy. Hence, the awareness of the strategy concerns also the intermediate level of management. Training courses were a functional activity programme translating this strategy into concrete facts. Such personnel policy is still continued (January 1996).

It seems that two theses could be advanced here:

1. The strategy of shaping human resources (and particularly its intensive dimension) paves the way for creating a specific definition of organizational reality along with its values and assumptions, which also have a feedback effect on the formation of such strategy (Konecki/Kulpinska 1995);

2. The strategy of shaping human resources (and particularly its intensive dimension) integrates the management, the personnel, and it affects the ties with the company.

The company has adopted a system of premiums dependent on sales. The premiums allow employees to observe a direct relationship between sales and pay. Hence, a thesis could be advanced here that sales orientation (as a part of the organizational definition of reality) is also promoted by an appropriate human resources management substrategy (here: a motivation system).

Another extremely important substrategy in Toffi's activity was a change of the product range, which is a change in the investment programme and the activity profile. This substrategy concerns internal changes in the company, which roughly boil down to 'changes in the field of production'.

All above changes started at Toffi (in the 1980s, following the turning point in its history, and the appointment of the leader to the managing director's position) not by privatization. The modernization strategy was developed by a team grouping all managers. It could be said that production changes are also connected with changes in the main field of activity, which is with the place of selling and customers. However, here a change in the main field of activity tended to outpace the economic reality in Poland (in the 1980s) instead of being directly related to the market not to mention the privatization process. Toffi 
changed its market giving up the Soviet market in favour of the Chinese and Western markets in 1980s.

An aspect of changes in the field of production are "changes in organization of work". These changes involved, among others, the liquidation of piece rate system, the computerization of production or the introduction of flexible working time for shop floor workers.

An important substrategy developed not until the 1990s is the 'marketing substrategy'. At its foundations lies sales orientation, where sales are the most important organizational value.

The company does not have the marketing department. Its place is held by the promotion department. It is planned that the department of market analysis and development will be established in 1996.

Rank and file employees are also involved in the implementation of marketing substrategy. The operation of sales units during free Saturdays shows employees how important "sales" are in the company's success. Moreover, employees distributed advertising leaflets of their company in the whole city and elsewhere in their free time, for which they were remunerated. Following the marketing campaign, the company's sales rose. Owing to this functional activity programme the employees' interest was directly linked with the company's interest and at the same time the employees began to perceive it. When promoting their company outside it, the employees „implement the marketing substrategy, which shows the essence of an activistic perception of the environment" (Konecki/Kulpinska 1995; Smircich/Stubbart 1985). Almost all foremen in the company are aware of the marketing substrategy. A similar situation can be observed at Elena, and to a smaller extent at Proc and Nika.

Toffi seeks a strategtic investor and intends to privatize itself. The managing director tries to win the whole work force for privatization all the time, although he has already got the approval of the most important organizational actors, i.e. three trade unions active in the company and the employee council. The director very frequently meets the employee council and also organizes meetings with the personnel.

The managing director places the following conditions before the potential investor:

1. Investment outlays should reach DM 5,000 - 10,000 million.

2. The company should get access to a distribution network in the West.

3. Strategic investor should reinvest profits yielded by the company during the first three years after its privatization.

The privatization substrategy at Toffi is closely related with the investment substrategy. Thus, organizational changes in the field of management and 
structural changes in this company occurred so far without privatization. They were an effect of efforts made by the organizational leader and the initiative group created by him.

\section{ELENA Joint Stock Company - employee partnership}

Elena has an offensive definition of organizational reality oriented at a drastic change. It is characterized by a positive, activistic and prospective attitude to the environment, an institutionalized and common marketing orientation, a need to maximize achievements, and paternalistic values along with such value as harmonious human relations. This definition rejects production orientation fully (Konecki/Kulpinska 1995).

The marketing substrategy is the most important substrategy in the privatized company called Elena. It was formulated following the turning point in its history in the 1990s. It should be noted that this substrategy is developed both at Toffi and Elena only in the 1990s (although the turning point at the Toffi occurred in 1981). Thus, a thesis could be advanced here that 'changes in the organizational environment (market reforms in the 1990s) force out the formulation of marketing substrategy to a bigger extent than the turning point and also privatization itself'.

Let us look now more closely at the motives, conditions and consequences of privatization at Elena to substantiate a thesis that there is almost no direct relationship between privatization and emergence of marketing substrategy. The main motives behind privatization were:

1. Desire to avoid the tax on wage increases above specified limits and create possibilities of raising wages. The latter motive induced the Employee Council and trade unions to accept privatization.

2. Desire to make the company independent and its management sovereign in their decisions. This motive dominated among the top management.

3. Desire to invest available or borrowed funds.

4. Desire to maintain a good renown of the company. That is the so-called strategic leverage already possessed by it (Obloj 1994:27). 
A review of these motives shows clearly that the intended impact of privatization on the companay's new marketing substrategy did not appear almost at all, with fiscal and investment motives being predominant here. ${ }^{9}$

An indispensable condition for implementing the above motives and the privatization process was the 'emergence of the initiative group' able to convince the personnel that privatization assumptions were correct. ${ }^{10}$ The other condition was 'finding persons willing to purchase' shares. At Elena $80 \%$ of employees hold its shares. Nonetheless, the majority interest is held by a small group of persons - the management board and managers (the initiative group promoting privatization). About ten persons hold $60 \%$ of all shares. This concentration of most shares allows, according to the management, to accomplish the main goals connected with the company's growth such as, for example, investments at the time the employees advance constant wage claims.

Thus, a consequence of privatization seems to be a 'psychic comfort in the field of management'. Moreover, there are fewer entities exerting a significant influence on the company's management (no employee council, a smaller influence exerted by trade unions). The privatization process produces also 'conflicts and tensions in human relations'. The social conflict as a consequence of privatization is confirmed mainly by the foremen at Nika, next at Toffi and Proc, and only lastly at Elena. At Elena it is confirmed by only a half of the foremen. The exisiting tensions are primarily connected with the struggle for power and with personal and organizational changes.

As it can be seen the privatization process itself is full of tensions and conflicts, because it is accompanied by the struggle for power and influence within the company.

For the privatization process to be carried out consistently it is necessary 'to normalize the social and organizational situation' in the company. At Elena this

9 The same motives predominate in the present decision about selling a $25 \%$ block of shares to a Bank. With the money received for sold shares the company plans to buy new machines and technologies shortly. It also intends to expand its distribution system. On the other hand, the public subscription of shares (in 1997) is motivated by a planned acquisition of other Polish cosmetic firms in order to create a holding. It is a common belief in the company that only a company being strong in terms of possessed capital can meet the challenges of Western competition and survive on the market.

10 Forming an initiative group and convincing employees about the advisability of privatization is especially necessary at the time when it is commonly believed that 'economy should not be forcefully privatized, and competition on the market will decide which enterprise is good and which one will go bankrupt' (it is an opinion accepted by foremen in all four enterprises under survey). 
condition appeared just before the formal act of privatization. At that time the new top management received the employees' approval for privatization. ${ }^{11}$

'Privatization' was here only an intermediary variable affecting the construction of marketing strategy. In 1991 the managing director established the marketing department. The director (today's board chairman) and the company's authentic leader is fascinated by the marketing know-how. Before joining the company he had completed a course of marketing and he is the main promotor of marketing activity at Elena. In this field he is strongly supported by the head of the marketing department. The director appointed the so-called marketing council in order to release marketing orientation and spirit and counteract production orientation, which was supported institutionally by the so-called 'production council' earlier. The marketing council seeks to develop market orientation within the company and it is one of functional activity programmes translating the strategy into the management's daily activity.

The marketing substrategy is in a way a driving force for developing the other substrategies of the company. There could be advanced here a hypothesis that 'the substrategy of changes in product range' is a derivative of the 'marketing substrategy'. A change in the product range follows the turning point. Many major refurbishments and investments were made at Elena in 1993.

\section{NIKA Ltd.}

Nika has a defensive definition of organizational reality oriented at survival. It is characterized by a negative and vindicatory attitude to the environment, which is not to be trusted. Such attitude is strengthened by a common assumption concerning human nature, which says that 'people cannot be trusted'. Organizational values of a traditional type seem to dominate here: 'production is the most important', as well as egalitarian values (Konecki/Kulpinska 1995).

Nika Ltd. commenced its repair programme with the restructuring of ownership. A healthier part of the company was privatized, and its main owner became the Agency for Development of Industry (ADI; $70 \%$ of shares). The remaining shares are held by other creditors, while the employees hold only 10 shares, which is a fraction of one percentage point of all shares. It was believed (especially by trade unions and the employee council) that the ownership transformation would solve such problems as debts and taxes on wage increases above specified limits, while the company itself would be run independently. Unfortunately, things did not turn out as expected. The ADI assumed the role of a central government organ making decisions about the company's future and

11 According to Polish law there should be an approval of a worker's council to privatize a state owned company in Poland. 
management (rather abstaining from strategic decisions). An organizational precondition for formulating the privatization substrategy was the emergence of the initiative group composed of the most important organizational actors: the Solidarity trade union, employee council, managers. The organizational actors tended to agree as regards the principal aspects of the company's transformation. It should be stressed that the strongest organizational actor was the Solidarity trade union, which brought about an untypical transformation as a result of strikes and pressures exerted on the Government. A consequence of the company's transformation were social conflicts caused by group redundancies in the liquidated part of the company and recruiting only some employees from it to its healthy part. Trade union ' $\mathrm{S}$ ' being an animator of transformations, which ultimately led to redundancies, simultaneously defended the employees and stipulations made with the ADI. According to these stipulations, about 800 employees were to remain in the healthier part of the company. Actually, for economic reasons only 450 remained. In this situation, trade unions were forced to fight and defend employee interests focussing their attacks on subsequent management boards of the company.

The privatization process did not pave the way for developing the company's development strategy for a very long time. The unsolved social and management problems suppressed the employes' energy and enthusiasm displayed prior to the privatization period and directly after it. The marketing substrategy was not developed in the company, although it had the vicechairman for marketing (in 1994). He claimed that it was impossible to design the marketing strategy as the company 'could not be steered properly', which means that it did not have a desirable system of motivation.

At present, the company does not have the marketing department (January 1996). The promotion department was also closed, and only the sale department operates. The absence of the marketing department is attributed to a small volume of direct sales on the market. Nika is primarily involved in subcontracting services for Western firms. Another explanation is the unavailability of properly qualified people who could run the marketing department. One of the reasons is that the the company cannot ensure an appropriate pay for marketing specialists from outside it (a similar situation is observed also at Proc).

Due to the shortage of working capital, attempts are made to effect changes in the field of production organization aiming at the reduction of production costs. There are some initiatives connected with organizing profit centres - one such project has been, in fact, already carried out in the tool-room. The company seeks also new investors in order to increase its working capital and investment funds. The first investments were not made until 1995. The shortage of funds made such investments impossible earlier on. The financial resources received 
from the Japanese Government's grant (amount to US\$ 500,000) were to be invested. The funds have not been fully used till now.

The changes in organizational structure were connected with the necessity of making personnel changes. Moreover, during the stay of a consultant in the company (a strong personality and the chairman of supervisory board), the production director was removed from the board structure. It was a deliberate move of the consultant wishing to show that production was not the most important aspect of the company's activity. Moreover, the consultant managed to integrate the employees, organized a team for solving concrete problems in the company and one strategic session despite objections raised by trade unions. It was during the session that the company's strategy was outlined. However, it was not formulated in a greater detail, because the consultant was soon removed from the company under pressures of the Solidarity trade union and the main owner.

In order to maintain production, export services and achieve 'the highest value such as production', the company tends to diversify production. The company in question produced CD players (untill March 1995), gas valves, intercoms, record-players, plastic packaging. It plans to launch production of yet other items. Some managers call such plans 'a conglomerate strategy'. This stylistic device replaces here other names commonly used in the company to describe such activities, e.g. 'a compliant service provider' or a firm willing to produce even a short series of a product to a concrete order. At the time the company wishes to produce a big range of various products, calling its activity 'a conglomerate strategy' justifies psychologically and socially the absence of a clear concept of its growth and goals.

Abandoning the production of the company's own CD player, which had poor chances to be competitive in the market, not until March 1995 points to an interesting phenomenon of attachment to the company's old image and identity. The management board wish to give up the manufacturing of products designed in the company, which cannot compete with Western products. However, it is very difficult both for the company's engineers and its board to resign from the feeling of their own value based on possibilities of designing own products. A certain contradiction in plans concerning the development of production can be observed here. Although the company's own products were abandoned, it still plans to launch a stereo set designed by its engineers. The company continues to launch its own products (January 1996). It looks like nobody can abandon the magic fascination with the company's own electronic products. Its image as a leading company in electronics in Poland during the 1980s continues to be extremely strong among the management, engineers and trade unions despite the fact that the conditions of its operation on the electronic products market have changed fundamentally. The old image of the company, which has not 
been redefined, is a heavy burden for its present operation. There is no human resources substrategy. The privatization has not changed much in the company.

\section{PROC Joint Stock Company- company listed on the Stock Exchange}

Proc has a definition of organizational reality that accepts changes in the environment and adapts gradually to them. It is a peculiar combination of an activistic and passive orientation. Production orientation continues to be present at Proc. Its clear expression is the system of pay giving preferences to employees involved directly in the production process. A significant role in maintaining such orientation is played by trade unions.

The privatization substrategy (selling stock on the Stock Exchanged Market) was one of attempts aimed at transforming the firm into a modern company.

The period before privatization was characterized at the Proc by strikes prompted by wage claims. Its employees expected that their wages would rise three to five times. It was one of motives (conditions) behind a common aceptance of privatization. Another motive was a desire to avoid the tax on wage increases above specified limits.

The main authors of the privatization strategy were the management board and the employee council, which worked together on the decision and the mode of privatization (capital privatization). The case of Proc confirms our general thesis that for the privatization process to be carried out effectively it is necessary to ensure an approval and an acceptance of the main organizational actors, who are equipped with a range of powers.

The company's privatization allowed to solve the problem of tax on excessive wage increases (consequence). Another consequence of privatization was an enhanced awareness of the employees as regards the principles of market economy and personel changes among the top management. Namely, the board chairman and the finance vice-chairman were replaced. Meanwhile, no changes were made among rank and file employees, although the management perceive the necessity of such changes (1994 and 1996). Neither did labour discipline and personnel management change: "A foreman is saying something and a sewer either understands something of it or not. If a German or an Englishman told her something she would understand it. It may sound like a brutal approach but you sometimes need a whip in this company" (statement made by the board chairman dismissed in 1995).

On the other hand, a consequence of the chosen path of privatization, which does not give any more significant number of shares to managers, is a lowered motivation of managers to get more involved in the company's operation and devote more time, energy and ideas to the company. There are some clashes between the main owner of the company (trustee W.) and the management, with the latter being more interested in and better acquainted with the company's 
internal situation and its market position than the main owner. Thus, for example, the board chairman is not equipped with powers to make decisions concerning investments. All strategic decisions, as well as quite often minor decisisons, concerning e.g. work force, must be negotiated by him with the supervisory board.

The 'privatization' of Proc did not pave the way for formulating the human resources management substrategy. Proc does not have a director in charge of human resources. Creating such post is defnitely not one of the company's top priorities.

Generally speaking, a lot has been preserved from the old wage system. Shop floor employees get a higher pay for overtime than others. The company does not have either an explicitly formulated policy of personnel training.

At the time when the board chairmen are frequently changed it is difficult to develop the company's strategy. New chairmen have to spend a great deal of time getting acquainted with its specific characteristics or diagnozing numerous dimensions of their activity. Moreover, they have to overcome the resistance of the old management towards themselves or proposed changes. The management tend to hide from the chairman information about many important facts or aspects of the company's operation.

Major investments began to be made at Proc after its privatization. In 1992 almost the entire profit, i.e. 25 billion zloty was earmarked for investments. Partly as a result of these investments it was possible to diversify the company's production and operations. At the same time Proc is becoming a trading firm expanding its sales department.

Proc has also purchased a computerized system of production control. This investment was meant to streamline rather management than production. The company has just launched new investments connected with establishing its own sales network and upgrading its management system.

An important aspect and a consequence of the investment substrategy are changes in organizational structure and in organization of work. The company has also found subcontractors sewing clothes according to its models. However, it continues to maintain a centralistic management system and generally an organizational structure of a state-owned enterprise.

Summing up it can be said that the investment substrategy could to be the most important one among all substrategies at Proc. It is underlined by all its managers and confirmed by investment expenditures and their share in total profits (1992-1993). The present board chairman also emphasizes the necessity of new investments. All this points to the fact that production mentality determining the above activities still exists at Proc. Thus, the privatization 
substrategy after five years of its launching has not changed production orientation at this company.

Proc does not have the marketing department either. A part of marketing activities are conducted by the sales department. After systemic changes in the economy there appeared only sales orientation at Proc. This is not a full marketing orientation as yet, although it marks its beginning. The company is aware of a close relationship between its economic situation and sales. However, it is not a dominant orientation at Proc.

The subcontracting production services for Western customers and production for the domestic market are two elements of the company's politics.

It was the privatization process itself which led to the emergence of the 'conflict of identity'. It forced the company to find partners and markets in the West. These markets do not accept the company's identity marks placed on products sold there. ${ }^{12}$

As it has already been mentioned, production orientation predominates at Proc, and its consequence is a priority given to the investment substrategy. There can be also found sales orientation in the company, which could led to the development of sales substrategy. Meanwhile, the marketing substrategy makes its way very slowly, which is partly due to the absence of marketing department and appropriate marketing specialists. There is no one clear strategy in Proc.

12 The Western customers even suggested that the company should change its name, but the management did not agree to that, as its name is commonly known on the Polish market. This is a reason for pride and self-identification of the management and employees with the company.

The lack of possibilities of offering the company's products under its own trademark is disappointing for the employees and they would rather have its trademark known to a broader public. The company's identity is known to a narrow group of customers (mainly domestic ones). Thus, the company's identification takes place on a limited social and market scale. The sense of identification with the company is restricted among its management, because many other potential customers are not aware that the products known to them are manufactured by Proc. Hence, it is no wonder that some people call Proc 'a drudge'. The vice-chairman for trade says: "we get fabrics and accessories, do the sewing, a little of drudgery, but such is the situation. We wish to preserve the company's name as its logo is already known in Poland". This problem finds its full expression in a paradoxical conflict of identity, that is in the necessity of assuming another trademark to survive at all as Proc with its own trademark. Without subcontracting services for the Western customers the company would not be able to manufacture products for Polish customers, who in turn know and appreciate the company's trademark giving it a strategic leverage in Poland. 


\section{Summing up}

Enterprise action strategies consist of several substrategies, with one of them being usually the leading substrategy. The strategies appear when a crisis takes place in the company or a leader (with a group of supporters) able to overcome the crisis emerges. It is synonymous with the appearance of the so-called turning point. Moreover, the strategies are a result of the offensive definition of organizational reality dominant in a given company more than the form of ownership.

If we recollect a definition of strategy we have to say that the most important part of it is the conception of a 'principle' inferred ex post from regularities present in empirically observable behaviors of managers. It can be said that the principle that regulates the actions of management and companies is an oscillation of activities and interactions around a dominant sphere of action (a substrategy) that emerge after a turning point and change of organizational definition of reality by a leader and his group. The oscillation concerns here the permanent referring to a dominant substrategy, e. g. substrategy of shaping of human resources in Toffi, marketing substrategy in Elena, partly investment substrategy in Proc. Such understanding of action strategy indicates on sociological aspect of economic and organizational transformations in Polish enterprises, especially when they are done from the inside of a company (Toffi, Elena, Nika, Proc) by managers of companies and not by the external and dominant strategic investor. ${ }^{13}$ Managers or initiative groups have to coordinate their ideas, visions through negotiations, persuasions, organizational learning, trading off , and other interactional processes. They communicate also about their vision of strategy to lower echelons of organization and to the other main organizational actors, e.g. trade unions.

At Toffi, the concentration on paternalistic values leads to a full implementation of the human resources management substrategy. On the other hand, marketing orientation is common among its management. It permits to lay good

13 There is a completely different situation only in the companies bought almost completely by strategic investor. Abet was the biggest producer of transformers in 1980s in Poland (distributive transformers). Crisis on the beginning of the 90s was a cause of looking for a strategic investor. An investor, a big international concern, bought Polish firm. The firm that buys almost totally a company has decisive influence on its strategy and the way of management. The privatization was done from the bottom thanks to the initiative group that was created in the firm. The further history of the firm is completely dependent on the strategic investor, according to our research. The main decisions are taken beyond the firm, in the headquarters of the concern. The strategy is connected here mainly with the method of management. The motto of management philosophy in Abet is: 'Global Business, Local Activity'. It means that local activity should be convergent with the general strategy of the firm. The structure of the firm and management is completely taken from the concern Abet. 
foundations for formulating the marketing strategy including the company's identity and its image. The marketing substrategy emerges when such drastic changes take place in the environment that earlier trading practices will not suffice to keep sales at an unchanged level (Toffi - state firm and Elena - private firm; 1990s). 'Hence, privatization is not a sufficient and necessary condition for the appearance of marketing strategy' (at Nika Ltd. and at Proc J.S.C., the marketing strategy has not been formulated as yet). Indispensable conditions for its appearance are:

1. drastic changes in the company's environment,

2. marketing and/or sales orientation, which means an appropriate definition of organizational reality at least among the board members.

It appears that employees of the companies under analysis do not participate fully in the construction of substrategies. Substrategies are formulated rather by leaders of the firm or usually by the board and managers of the companies. These are only privatization substrategies which are developed jointly by all major organizational actors, i.e. employee councils, trade unions, directors and managers of companies. A precondition for carrying out the privatization procedure is the emergence of the initiative group able to overcome employees' resistance and win their support for assumptions concerning privatization. Participation involves here also another necessary condition of privatization and namely finding investors willing to buy shares or equity. At Elena J.S.C., which is an employee-owned partnership, we are dealing with a common ownership of shares among employees. On the other hand, Nika Ltd. is characterized by an active involvement of trade unions in the process of privatization and a negligible participation of employees in shareholding. Such situation reflects negatively on later relationships between the management and the personnel.

Participation or rather implementation of the marketing substrategy by almost all employees takes place in companies having an offensive definition of organizational reality (Toffi - state company and Elena J.S.C.) and not in a vindicative way (Nika Ltd.) or technocratic (Proc J.S.C.). Hence, the 'privatization' variable is not a necessary condition here (only an intermediary condition) paving the way for the appearance of marketing substrategy. This function is taken over by changes in the environment and their perception by the managers group and leaders in organization.

The substrategy involving a change in product range seems to be a derivative of the marketing substrategy and it usually appears after the turning point in the company's history. Its authors are primarily the management board and managers. At Elena J.S.C. and Toffi State Company the foremen clearly perceive the effects of this substrategy unlike at Nika Ltd. where most foremen do not perceive any product differentiation, although it has, in fact, taken place. 
Summing up the above observations it can be said that at the present time the strategies of activity in the companies under study are developed in the long term process during action but without participation of several major social actors in these companies, that is trade unions and employees with the exception of privatization strategies. On the other hand, the intermediate management level perceives the already formulated strategies in the companies with an offensive definition of organizational reality. The 'privatization' variable is not a necessary condition in formulating substrategies. Privatization can be an intermediary condition influencing the construction of investment, sales or marketing substrategy if the funds yielded by privatization of the company can be used for investment purposes. On the other hand, the appearance of a leader and an initiative group linked with him is an indispensable condition affecting directly the formulation of strategies (substrategies) in companies regardless of their form of ownership.

\section{References}

Berger P./Luckmann Th. (1983): Spoleczne tworzenie rzeczywistosci (Social Construction of Reality), Warsaw.

Crozier M./Friedberg E. (1982): Czlowiek i system. Ograniczenie dzialania zespolowego (The Actor and the System. Constraints on Collective Activity), Warsaw.

Golata K./Szoszkiewicz A. (1996): Egzamin wstepny, (Entrance Exam), in: Wprost, 9.06.1996, no 23.

Konecki K. (1989): The Methodology of Grounded Theory in the Research of the Situation of Work, in: Polish Sociological Bulletin, No. 2, pp. 59-74.

Konecki K./Kulpinska J. (1995): Enterprise Transformation and the Redefinition of Organizational Realities in Poland, in: Dittrich E./Schmidt G./Whitley R. (eds.): Industrial Transformation in Europe, London.

Kotler P. (1994): Marketing. Warsaw.

Obloj K. (1994): Strategia sukcesu firmy (Strategy of Firm's Success), Warsaw.

Smircich L./Morgan G. (1982): Leadership: The Management of Meaning, in: The Journal of Applied Behavioral Science, No. 3, pp. 257 - 273.

Smircich L./Stubbart Ch. (1985): Strategic Management in an Enacted World, in: Academy of Management Review, No. 4, pp. 724-736.

Stoner A. F./Wankel Ch. (1992): Kierowanie (Management), Warsaw.

Strauss, A.L. (1987): Qualitative Analysis for Social Scientists, Cambridge.

Strauss, A. L. (1993): Continual Permutations of Action, New York.

Zelmer Z. (1992): Public Relations, Kreowanie reputacji firmy (Public Relations. Promoting the Firm's Reputation), Warsaw. 